\title{
Museum Architecture Matters
}

\author{
Paul Jones* University of Liverpool
}

Suzanne MacLeod** University of Leicester

\begin{abstract}
Using a series of illustrative examples throughout, we make an argument for the inclusion of sociological studies of museum architecture in museum studies, as well as advocating a series of methodological positions for future research. In short, the aim here is to provide students of both the museum and architecture with a route into the field - as well as a preliminary bibliography - while making the case for the need for increased engagement with the physical material of museums. Drawing on the widened scope of analytical possibilities represented by contemporary sociological analyses of architecture and the built environment, the paper sets forward an understanding of museum architecture as having a complex and entangled relationship with the museum institution and the variety of users of such (both actual and potential). Developing a threefold typology with the polemic intention to encourage increased research engagement with museums' architectural forms, the paper is motivated by a desire to both showcase and advocate for the wide scope of analytical possibilities associated with sociological analyses of museum architecture.
\end{abstract}

Key words: sociology; museums; architecture; design; material culture.

\section{Introduction}

Keep the weather out? Make money for architects and contractors? Walls to hide behind? Display wealth or good taste? Sites for productive labor and entertaining leisure? Establish ownership? Store stuff, or sell it? Prevent some people from coming inside? Prevent others from leaving? Buildings do all that, and much more. It is surprising that they have been so rarely theorized by sociologists. (Thomas Gieryn, 'What Buildings Do', 2002: 35)

Museum architecture not only provides the material built contexts within which museums exist, it also crucially adds meaning to the objects and interactions in these 'spaces of encounter' (Boast 1991). The initial observation that objects and collections placed in one context will look, feel and signify differently, when placed in another (see for example Wilson and Hale, 1993; Bourriand 2002; Becker, [1982] 2008) provides rationale enough to study museum architecture. Similarly, it has been found that the built, designed forms of museums and galleries are bound up in visitors' experiences in complex and significant ways; the evidence available suggest that as visitors move through museums, they map their experiences physically, as well as emotionally and imaginatively (Bagnall 2003). Furthermore, museum professionals - the people who occupy these spaces on a daily basis - utilize the architecture of museums in all kinds of ways. In the process they shape the materiality of these sites, adding meaning to different kinds of relationships and spaces in all kinds of contingent and unpredictable ways as they go (MacLeod 2013; Steets 2015).

In short, museum architecture is bound up with key relational practices, crucially including claims-making about the social world that the museum is fundamentally implicated in (Fyfe, 2011). In general terms architecture adds authority to some discourses, and is part of a 'resource to allow [some] claims to gain believability and persuasiveness' (Gieryn 2006: 6). The 
way in which the museum's mission is reflexively expressed in the language of architectural space requires that the researcher study just how it is that museum buildings are put to work in various ways and in differing contexts. As will become apparent, from our point of view the study of museum architecture opens up much potential to sharpen our understanding of the museum more generally.

But, if we are to do more than merely encourage researchers to take museum architecture more seriously than they do, where do we begin? What basic understanding of museum architecture might we need in the first place? And how and why might this offer an important starting point for those seeking to understand more about museum architecture and design? This paper sets out to provide some sociological theories and approaches that will be of interest to students of museum architecture. We argue that, although not the only way of approaching the analysis of the built forms of museums and galleries, sociology nonetheless has something vital to offer to those seeking to understand the production, actions and significance of museum buildings. At the centre of this argument are a number of observations, that when taken together sketch out key approaches to socially-located understandings of museum architecture. To this end we articulate a number of possible lines of inquiry with respect to the study of the built environment of the museum.

First, the built forms of museums and galleries are an integral part of a complex world; far from aesthetic objects floating free of that social context, buildings are produced in the midst of complex cultural and political-economic forces (King 1980; Marcus 1993). As such they are integral to the narratives of culture, economics and politics that museums themselves produce. Secondly, architectural forms - the material stuff of museums and galleries - are, as a result, inevitably caught up in a variety of ways in unequal social relationships and the politics of inequality (Bourdieu and Darbel 1991; Gieryn 2002, 2006; Jones 2011; 2015; Steets 2015). Thirdly, built forms are produced as much through occupation and use (Hillier 1996; Fallan 2008) as they are through processes of design. Design itself is to be understood as a set of practices (Fuhrmann 2015). In other words, and at the risk of over-simplifying things, architecture is social; it is occupied by different groups in different ways, and this occupation and use sees buildings remade long after the architect has left the scene. Museum buildings are caught up in human experiences and in ways that warrant theoretically-informed and empirically-engaged study if we are to make sense of what is goes on in them. Museum architecture is then a social process; it is in a constant state of production through the actions of a whole network of interdependent actors who are the authors of its meanings.

The museum, as we know is a building that commands authority through the 'authentic' fragments that it contains. In our view the case for conceptualizing the museum as a dynamic space that is made meaningful through the interactions of space, objects, sociality, and the very meanings that flow from that interaction is a compelling one. It is a way of studying museum architecture that opens things up; it enables us to move beyond static typologies of museum design and stories of great architects. It also allows us to transcend limiting notions of the history of museum architecture as one of competing demands of different functions, say education or entertainment. Instead it encourages researchers to engage with the museumas-practised, or perhaps the museum as practice. To understand museum architecture is, therefore, to understand the ways in which it is both produced in the context of institutions and as it is relative to wider social forces (as opposed to its being relative to abstractions).

Viewing the physical museum as an 'assemblage' of people, material and practices in a dynamic state of making, means that researchers need to move beyond notions of architecture as the static output of an architect, as a contribution to some kind of stylistic development or architectural canon or as an inert container for museum practice and focus instead on the production, contingencies and implications of built forms. In museums, which are organisations that claim to provide opportunities for diverse audiences to access creative and critical lives, such critical thinking is vital. There are, for example, those researchers who have argued that museum buildings are caught up in some of the most negative and oppressive aspects of our social world, part of a system whereby social inequalities are normalised and social space is de-politicised - turned into spaces for various forms of non-critical consumerism and celebrations of civic and social disconnection (see for example Miles, 2010). Here, museum buildings are understood as a constitutive part of an active force in the 'modern disease of 
individualism', working against processes of community cohesion as a result of the 'cult of individualism in architecture' (Glendinning 2010). In museums, there are plenty of anecdotes of museum buildings that are understood to in different ways go against the grain of the values and objectives of the organisation (see MacLeod, 2013). Such observations, often apocryphal but not necessarily less revealing for that, have prompted discussions of 'other' ways of designing and occupying museum architecture. It is against this backdrop, that our paper draws together currently disparate debates with the aim of encouraging and contributing to a conversation about the sociology of museum architecture. We suggest a threefold typology organized around key sociological approaches to the study of the built environment of museums. Our paper's structure reflects this typology.

Firstly, we assess the contention that the form of museum architecture expresses a symbiotic relationship with social order, that is, that it reflects major political, economic, and cultural shifts. Secondly, we provide an overview of the research literature, which draws much from Science and Technology Studies (STS) and Actor-Network Theory (ANT) and which teases out the relationships between buildings, people and objects. This general approach is useful in focusing attention relentless on the practices that underpin the creation of the museum; as such it owes much to the social constructivist and ethnographic traditions in sociology (caveats below). Thirdly, and in what is best described as a methodological operationalization of the perspectives articulated in the second section, we assess the possibility that researchers can study architects and other design professionals as they go about making the museum. Of course, this approach is contingent on being in the right place at the right time, and securing access to the design practices of architects, but it opens up the beguiling potential to be there as the architectural authoring of spaces is actually happening.

This threefold typology - which owes much to previous analyses of architecture developed by us both (MacLeod, 2013; Jones, 2016) - is a purposeful description designed to organise sociological engagement with the built environment of museums. As is the case with any typology, there are numerous exceptions that disrupt the boundaries, and lots of studies that cut across our categories. So, in what follows we are less concerned with defending this threefold distinction than in discussing what has been, and could further be, illuminated by sociological study of museum buildings. We hope that the paper will help to position museum architecture as fertile ground for sociological research.

\section{Museum Architecture as Social Order}

Understanding architectural productions - buildings and the spaces between them ${ }^{1}$ - as both reflective and constitutive of the particular sets of social arrangements from which they emerge has been a starting point for much seminal sociological analysis of the built environment (for example, Tafuri [1976] 1999; King 1980; Markus 1993). This approach has yielded many rich insights concerning architecture's relation to power, and the ways in which architecture is implicated in processes of social reproduction. With respect to museums in particular, understanding their built forms relative to social order contains the promise of situating these modern cultural institutions in the structural conditions of action that give rise to them.

This particular critical sociological imagination was in evidence in some early sociological studies of museums and art institutions, the most influential of which is arguably Pierre Bourdieu and Alain Darbel's The Love of Art (1991). In keeping with his wider theory of class and consumption, which by now constitutes the dominant approach in UK sociology, Bourdieu analysed empirically the ways in which cultural institutions work to naturalise and legitimise the social order, depoliticising aesthetic - read social - judgments and hierarchies therein. The Love of Art surveyed visitors to art museums across Europe and showed that museum attendance increased with higher levels of education and that museums were in fact 'almost the exclusive domain of cultivated classes' (Bourdieu and Darbel 1991: 14). Bourdieu and Darbel characterized public museums as sites that valorised certain capitals; the reproduction of hierarchies happened in part through the celebration of cultures and aesthetics of a particular, classed section of society (on Bourdieu and museums see Fyfe 2011; Prior 2005). In this account, museums were positioned as a sphere of contestation and 
competition, rather than one of consensus (Bourdieu 1984, 1991); it was through differential access to cultural socialization that the middle classes learned to appreciate, celebrate, and constitute 'legitimate' forms of culture.

The architectural environment of the art museum played a part in Bourdieu and Darbel's accounts of processes of classed cultural socialization, not least as the 'the untouchability of the objects', 'religious silence', 'sparse' and 'uncomfortable' surroundings, 'grandiose' interiors and features such as 'monumental stairways' signalled its difference to everyday life and created for some a sense of belonging and for others, a sense of exclusion and arbitrary devaluing (Bourdieu and Darbel 1991: 112; for a critique see Bennett 2007). This analysis is suggestive of a close correspondence between the broader elite and elitist project of the museum and its architecture; the built environment is here reflective of the sets of structural conditions in which it emerges.

In a similar vein, and drawing on Bourdieu, Carol Duncan and Alan Wallach explored the museum experience and the way that the physical placement of artworks in the Museum of Modern Art (MoMA) in New York transformed 'ideology in the abstract into living belief'. They argued that social values were embedded in the architectural structure of MoMA - in its built forms, physical arrangement, interior decoration and layout of collections (Duncan and Wallach 1978, 1980; Duncan 1995). Of central concern here was the exclusionary and divisive nature of museum experience. They argued that the framing (pun intended) of art, and the story of art at MoMA, purged the museum experience of the everyday and the mundane, creating instead a spiritual and detached experience of art. In the resulting ritualized experience, abstract values about nation, about art and about one's own place in the social order, were made visible and, through the social process of museum visiting, internalized and transformed into 'living belief'.

Thus, Duncan and Wallach acknowledged the architecture of the museum as a dynamic social and cultural production, and as just one element through which social order is legitimized and reproduced. However, the nuanced processes of how the built environment of the museum is implicated in the social construction of the museum is absent Their main concern with art history ensured that the focus was, in the main, on the iconographic elements of architecture and the perception of images by an imagined user. Architecture here is a system of signification and an assumption is made of a tight fit between the processes of production, the text itself and its reception by an imagined user (oftentimes stripped of gender, class, race and other lifeworld characteristics) (Macdonald and Fyfe, 1998: 5). In their account then, architecture can be understood as 'congealed ideology' (Forty 1996), an ideological text to be read; the realities of visitor experience are pushed to one side in favour of an important, but inevitably partial, reading of the character and actions of museum architecture.

Awareness of nineteenth-century museum architecture as part of a political-cultural project, is perhaps most evident in Tony Bennett's seminal study The Birth of the Museum (1995). Bennett drew heavily on the work of Michel Foucault (particularly [1970] 1997) in tracing a 'history of the present' of the museum, positioning the nineteenth-century museum as part of a new form of disciplinary institution that had emerged out of the Enlightenment. The transparency of the museum's architectural space meant that visitors could see themselves being seen; as a museum visitor, a citizen circulated 'between being subjected to the controlling gaze of others to, in turn, exercising such a gaze' (Bennett 1995: 48). The museum made 'society transparent to itself' (Bennett 1995: 48). Thus, Bennett argued that the architectural forms of nineteenth-century museums were solutions to the need for disciplinary cultural structures that created docile bodies, with architecture implicated as a technology for 'fashion[ing] human contact' (1995: 48; see Trodd 2003 for a critique). Thus, a Foucaultian perspective situates the museum relative to the political and governance regimes that originate far outside its walls. Seeking affinities between disciplinary governance and the form of the museum certainly opens up the potential to situate its architecture in broader conditions of political-economic action. But at the same time this starting point risks a one-sided emphasis on structural context at the expense of active engagement with the specificities of forms, practices, and motivations within the institution itself (Prior 2005).

The museum, we are reminded by Felix Driver and Sonia Ashmore (2010), does not stand still, and capturing the dynamic animation of the site is precisely what makes these sites such alluring and challenging ones for sociologists. For its own part, architecture also raises a 
number of thorny problems for sociologists, and these take a specific form in the context of the museum. The work of Michaela Giebelhausen $(2002,2003)$ has been amongst the forefront of scholarly analysis of museum architecture and has done a great deal to identify and analyse key shifts in the paradigms that have shaped museum design. Giebelhausen's work provides a framework within which key museum designs can be convincingly situated (also see Brawne 1965 for such); however, and distinct from the art-historical reading that underpins her approach, a sociologist would perhaps be wont to disrupt these hierarchies and narratives with respect to their practice and the ways in which power and canonisation operate within typologies of architecture (Bonta 1979; Forgan 2005). Ostensibly 'objective' histories of museum, such as those drawn together by Giebelhausen (2002), thus become orderings demanding analysis rather than illuminations of essential values of buildings and their internal relations.

What can be missing in this work in general is a detailed study of the complex processes through which museums are produced; local-rational forms of knowledge and practice can be flattened out or overlooked altogether in the course of finding evidence for broader overarching trends. Indeed, a danger with architectural-historical accounts can be precisely that they tend to become removed from the sociality and dynamism that characterizes museums (Latour and Yaneva 2008); cultural typologies tend to smuggle in judgments of architecture and architects, which - as has been noted (Bourdieu and Darbel 1991) - are orderings demanding the application of a critical sociological approach in their addressing. Furthermore, distance from the social action can lead to standpoint errors of all kinds, and missing the radically different practices that take place in ostensibly 'the same' style of building, or even the same building at the same time (Brawne 1965; Bonta 1979; Latour and Yaneva 2008; MacLeod 2013; Steets 2015). Those who have pursued museum architecture as social structure, have often tended towards the general at the cost of getting close to the ways in which architecture is actually implicated in the social relations between the objects, institutions, people, and narratives that constitute the museum assemblage. In other words, such studies tend to start with a theory of the world, and to find evidence for that theory in architecture.

Over-reading of architecture - and finding meanings that simply confirm one's prior thoughts - is problematic, as problematic as ignoring the built structures of the museum altogether... Similarly, the physicality of architecture and the long-established tradition of talking about and focusing on the physical forms of buildings, can lead to reductive associations between certain materials, types of construction or architectural details and specific social meanings. If our argument here is that canonization is a problematic, then neither is architecture an infinitely open text that sociologists can read in any way at all to fit a priori assumptions of analysis of other things. In other words, there is not necessarily a neat relation between power relationships and their architectural expression (there are of course affinities that can be studied empirically, as is argued in Jones 2011; MacLeod 2013; Steets 2015).

One way to avoid this pitfall is to explore the discourses which are placed onto and within which certain architectural forms, materials or details are utilized and put to work, in making particular claims. An example of this sensitivity is to be found in Annette Fierro's (2006) work on glass and the ways in which glass was, for example, positioned in political and architectural discourse surrounding the Grand Projects of Paris in the 1980s and 90s. In Fierro's account, glass is a building material with significant symbolic associations to the discourses of transparency so common in European political discourse. But these connections are context-specific and contestable, not least as glass has a variety of symbolic affordances (for example with respect to political tropes of democracy, or discourses of public-private).

While the museum is not reducible to architecture, questioning how architecture is mobilised to 'do' things in specific contexts - such as '[stabilizing] social life [giving] structure to social institutions, durability to social networks, persistence to behaviour patterns' (Gieryn 2002: 35) is an extremely fruitful line of inquiry. The clutch of studies discussed here help us recognize the ways in which buildings can take on the values, priorities and meanings that are derived from i) the powerful political and economic individuals and institutions who are primarily the commissioners of museum buildings or ii) from sociological readings derived from a strong analysis of social order. However, and with respect to the former point, while museum architecture is always commissioned and designed with particular uses, users and projects in mind, as the next section shows, these aspirations seldom survive contact with reality (Lefebvre 1991). 


\section{Museum Architecture is in Use}

If the approaches discussed in the previous section seek to stabilize architecture vis-a-vis social order, another possibility for researchers is to study the animation of museum architecture as a result of use. This is a 'sociological' starting point; any such analyses must avoid metaphorically freezing the building in aspic, and understand architecture not as a stand-alone piece of art (Wolff 1981; Latour and Yaneva 2005 for critiques) but as a site for all sorts of sense-making social actions. Here, we are concerned with the animation that bodies - of visitors, museum professionals, artists, volunteers, etc. - bring to architectural spaces through their interactions and how built forms - in the museum this might also include exhibition hardware and the layout of collections - are utilized to different social ends. This general approach owes much to the ethnographic tradition in sociology (caveats to follow).

Museums are social spaces used by lots of different people in lots of different ways. Studying how use transforms or, to put it another way, produces museum architecture, is sometimes referred to as domestication (Steets 2015), that is a concern with the ways in which we change environments through dwelling in them. Illuminating the practical character of human-object interaction means being attentive to patterns of practical use, unfettered by a rarified conception of architects and architecture. Howard Becker [1982] 2008 makes a similar argument with respect to studying art worlds. So, prosaically, it is through the every-day turning of door handles - or by passing pieces of paper through a hole in the floor, an internal communication strategy routinely employed by the education team at the Walker Art Gallery in the 1950s (MacLeod 2013) - that museum buildings become bound up with certain types of action and experience.

Sociological analysis into architecture has drawn much from Science and Technology Studies (hereafter STS) and Actor-Network Theory (see Fallan 2008 for a lucid and comprehensive summary of ANT approaches to architectural analysis, and Latour and Yaneva 2008 for an operationalization of the approach to revealing the animation and dynamism of architecture-in-use). In short, and to gloss highly nuanced arguments, these approaches suggest the necessity of including analysis of objects and technologies as an integral part of social life. If such a reminder was necessary in social science (Latour 2005) it is perhaps less so in museum studies, where object histories and material cultures have always loomed large in analysis. Still, there are many insights to be derived from a pragmatist approach that begins with description. An example is to be found in Yaneva's richly descriptive account in which she unpacks the interactions between people and 'non-human actants' (objects and technologies) associated with the installation of a bus as part of an exhibition (Yaneva 2003). A key line of inquiry concerns the ways in which architecture becomes practiced-read animated - through design and use; close attention to often-unremarked elements of practice and care in description are hallmarks of Yaneva's work.

Although not addressing museum architecture directly, but nonetheless making points pertinent to the current discussion, Michael Guggenheim has also studied the ways in which changes in building's uses to/from sacred ones reflect something of architecture's status as a 'mutable immobile' (Guggenheim 2013). That is to say the building is a structure within and around which meanings and practices become more or less stable, themselves contingent on the efficacy of certain key architectural interventions. In Guggenheim's account, religious buildings come to be recognized as such as a result of a panoply of meanings and interactions that are stabilized vis-a-vis architectural material (Guggenheim 2013). An important insight from this research is the need for those studying museum architecture to carefully observe the specific uses and interpretations of interactions between humans and designed spaces. Pushing this observation in a structural-anthropological direction (for example, Levi-Strauss 1995), a concern with patterned and recurrent behaviours and meanings can still illuminate something significant across sites, whereas focusing on one-off changes can lead to a misreading of their significance, or relatedly, an aggrandizement of the researcher's reading.

Changes to the physical forms of museums are often bound up with a putative change in organizational culture, but as any sociologist will tell you, the social world is not always neat and predictable; changes in space do not always lead to a corresponding (intended) change in practice (Lefebvre 1991). That said, there are numerous examples of museums where their 
organizational values and ambitions have changed, and where they may then be limited or restricted in some way, by their physical, built forms. At the Imperial War Museum North (IWMN), for example, staff became increasingly disillusioned with the architecture of the brand new, purpose-built museum, holding it in part responsible for a lack of repeat visitors as a result of its highly expressive forms and explained the - architect-intended - 'discombobulation' (Bagnall and Rowland 2010) as putting off potential museum visitors (MacLeod et al. 2014). Analysis suggested however that visitors to the museum were not made aware of, or exposed to, the vision and values of the IWMN organization as a direct result of the staff reverence for the iconic architecture and resulting reluctance to domesticate (Fallan 2008) the building; indeed, one of the research's recommendations was that the staff should feel able to inhabit the building less passively, and leave traces in the process, for the values and work of the museum to be evident to visitors and remake the museum (MacLeod et al. 2014).

Here then, we have an example that is not so much a matter of the material form of architecture going against the grain of museum professional practice, but of a professional reverence that is underpinned by the building-as-aesthetic object. In this case, and quite aside from the building's material affordances (Steets 2015), the building's consecration by architectural and non-architectural publics alike was ultimately limiting the work at hand. This opens up the possibility that consecration by the art world, the media or the public, means that 'museum architecture too often becomes the real art work, overshadowing what is inside' (Shiner 2007). In the words of critic Hal Foster 'a giant spectacle-space that can swallow any art, let alone any viewer, whole' (cited in Shiner 2007). Such work can polarize analyses of museum architecture, with highly normative outcomes predictable on the basis of familiarity with the author's oeuvre; witness, for instance, the ongoing controversy surrounding the Bilbao Guggenheim, which is simultaneously heralded and condemned as architecture that 'serves the art inside' (Shiner 2007) or as a consumptive space more akin to a shopping centre than a museum.

These considerations lead us directly to the question of meaning and to the problem of how the world appears in the consciousness of the social actor. Here we should note the importance of ethnographic social research (Fuhrmann 2015) and of phenomenological sociology with its commitment to understanding the social construction of reality (Berger and Luckmann [1967 1991). In drawing on these perspectives, sociological research has revealed the myriad ways in which social groups experience and respond to the museum (Woodham 2009; Bagnall 2003). If we are to take seriously the proposition that visitors are active participants in the experience of the museum, then we must factor in 'the impact of buildings in terms of their architectural appeal to the emotions' (Forgan 2005: 572). Analysis of class, gender, ethnicity, and other life-world factors shows how people bring different things to their interactions with, and their interpretations of, museums. Extending this analysis towards the material (as is encouraged by Steets 2015), certain forms of museum architecture are experienced by many as hostile to their capabilities and bodies. There is, we believe, much scope for a very productive marriage between those approaches that have analyzed the disabling nature of architecture (Imrie and Kumar 1998; Imrie 2012; Jones 2014) and those who have studied museum visitors' perception of, and practices in, the sites and settings of museums.

It is arguably the case that the close and deep descriptions associated with STS and ANT approaches can sometimes miss the connections between architecture and broader contextual relations in which buildings are commissioned, designed, and used (Müller and Reichmann 2015). Of course, from the perspective of this tradition, a priori 'contexts' such as capitalism, democracy, or even society itself, may be considered false stabilities which, when one goes looking, appear everywhere or nowhere (Latour 2005). From these approaches we are reminded to pay attention to the nuance and specificity of both architectural production in situ and in vivo. From these perspectives, it is a mistake to focus on the architecture itself too much - museum architecture is used and made and interpreted in practice. Where case analysis suggest buildings are important, then the sociological researcher must analyze and specify how and why this is so. Alternatively, studies of the ways in which museum users 'workaround' architectural spaces of the museum, or alternatively how some design 'goes with the grain' of practice, can also be illuminating of architecture-in-use. 


\section{Studying the Design Practices that Produce Museum Architecture}

Of course, it is not just 'non-architectural' users such as visitors and curators that make architecture; it is an authored material construction - typically made by professionally-qualified architects and commissioned with particular outcomes in mind - that is reflective of particular intentions with respect to future (social) use and meaning (Yaneva 2009; Steets 2015). Getting close to the motivations, decision-making and practices in context underpins ethnographic approaches in sociology, which have in turn led to a whole tradition of studies of design professionals in particular; many sociological scholars have embedded themselves in architects' firms and carried out in depth studies of architects' working practices and sense-making (Cuff 1991; Fuhrmann 2015). The starting point in general terms is to access and study empirically the practical things that architects do in studios and on building sites when designing museums.

One way to study architecture is to follow architects and the other professional actors who do make a series of design interventions to affect certain outcomes that shape the museum literally and metaphorically. Buildings are of course located in particular places and they change over time, as do organizations. A recognition of this opens up the possibility of tightening our focus and looking at moments of architectural change in particular. In studying architecture as practice or production we must take care to not assume that the researchers are the only ones in the room capable of sociological insights into architecture and its social impact. Dana Cuff's study Architecture: The Story of Practice (1991) sees architects emerge as a highly reflexive group, whose own political and cultural positions are oftentimes at odds with those of their clients. Drawing across to the study of museum architecture, it could here be observed that in many cases, the state is the client and architects' motivations should not de facto be aligned with such by sociologists (in fact one of the hallmarks of architects' practice is to be able to refract such reliance into a more aesthetic/symbolic capital; this does not always amount to a flat rejection of the client relationship (Cuff 1991; Jones 2009).

Another line of investigation for sociologists of museum architecture and design practice is to include analysis of what, in Robert Harbison's words (1993), are the unbuilt and the unbuildable. Many ideas for museums have never been realized, for a whole host of reasons. The objects and imaginings, the models, drawings, planning applications, are in themselves artefacts and visions that reflect and help construct such projected architecture (for different stripes of analysis of architectural models see Yaneva 2009; Jones 2015). Another possibility is to identify a space in which architecture is implicated in a struggle over museums. For instance, one might follow the work of Hélène Lipstadt (1993), a thinker who has drawn extensively on Bourdieu, in assessing architectural competitions for the award of commissions and with an eye to the conflicts over symbolic and material capital. Lipstadt shows how the competition represents a struggle to define the social parameters of architecture itself, not least as projections for the future which need to be realized and made legible (1993). As was also argued above, 'buildings - their sites and surroundings, their internal spaces, their external facades - all have qualities that affect both regular inhabitants and temporary visitors' (Forgan 2005: 581). It is thus that buildings and collections and people relate, and implicate each other (Driver and Ashmore 2010). Understanding how the exploitation of such affectiveness is crucial to architects' design practice (Jones 2014; Fuhrmann 2015) as well as studying professional designers as they go about delivering highly prestigious commissions for museums should be one aim of the sociological analysis of museum architecture (Forgan 2005; Jones 2011; MacLeod 2013).

One of the present authors analyzed the unbuilt with this aim in mind, namely by paying attention to the claims-making, positioning, and form-making associated with the competition and public participation surrounding the never-realized first iteration of what eventually became the Museum of Liverpool (originally part of Will Alsop's controversial 'Fourth Grace' scheme). Not only was this museum architecture mired in all sorts of controversies that eventually led to its collapse (Jones 2011: 115-40), there were also, it was argued, a series of attempts to engage a variety of publics with visualizations concerning the realized space (also see Jones, 2015 for a non-museological example).

A coda to this general approach to study can be found in Actor-Network Theory, and in particular the invocation from one of its leading lights, Bruno Latour, that researchers should 'follow the controversy', that is find the friction and struggles as they can be a way in to people articulating their version of what matters and their stake therein (Latour 2005; 
Latour and Yaneva 2008; Yaneva 2012). Architecture is often central in these controversies (Yaneva 2012). Whether they concern the aesthetics of the building, its functionality, its costs, or its symbolic value, studying these is a 'way in' to analysis of the museum as site. Forgan's analysis of the controversy surrounding the Swedish Museum of Natural History foregrounds the 'intense debate and conflict' that centred on the ways in which 'a system of knowledge was [perceived to be] encoded into the building' (2005: 577; our emphasis and insertion). Indeed, museums are frequently highly contested sites, around which arguments about meaning circulate. Despite the significant potential here, there are very few studies of museum design that have adopted this approach.

The pragmatist description of Sabagh (2001) reveals much about the architects' crucial role in the making of Tate Modern; revealing something of the micro-politics of what was a major project. This analysis tells us something about the jumble of aesthetic and prosaic questions where should the toilets go, and how many should there be? - that became crucial decisions made and not all of which saw the architects involved. Should one be keen to abstract, these discussions could be understood as going to the heart of debates concerning the form and function of the contemporary museum, but Sabagh's account is notable for eschewing such readings to create space for a descriptive telling of the role of architects in decision-making around the development.

\section{Conclusion}

To mangle Karl Marx's observation (Marx, [1852] 1970: 96) architects make museums, but not necessarily in conditions of their own choosing. Design takes place in circumstances that already-exist. It is for this reason amongst others that Thomas Gieryn suggests that sociologists should take architecture seriously, but not too seriously (2002). Foregrounding architecture at the expense of the wider social production of the museum represents a kind of reductionism. While we think it would be reductive to argue that the architecture is the museum (Giebelhausen, 2002), we do nevertheless want to suggest the importance of theoretically informed and empirically-grounded studies of the built environment of the museum as an object of sociological research.

As a site of sociality and assemblage of otherwise disparate objects (Yaneva 2003) themselves to be understood as the outcome of social analysis on behalf of museum professionals and others (Fyfe 2011) - museums provide a case par excellence of the relationality that is associated with the material (Steets, 2015). Against this backdrop, museum architecture is not an object floating free of the social world, or a passive silo in which this assembling happens; architecture is itself a social production shaped by and giving tangible form to social relationships and structures (Lefebvre 1991). The specificities of exactly how and why museum architecture takes the form it does, and the implications of such for subsequent practices are precisely things that can be studied empirically by sociologists attuned to the interplay between materiality, claims-making and the museum; here we have argued that three general lines of inquiry - which are not mutually exclusive and in practice are often entangled - can offer productive and useful 'ways in' to this fascinating and challenging task.

There are many things to remember when studying museums, which are such beguiling sites for sociologists and others interested in buildings and society (King 1980). Sociologists are not architects. Our analyses are not realized as buildings and a sociological way of seeing does not offer a privileged perspective on architectural meaning. Sociologists do though, we suggest, have something distinctive and important to add to the illumination of museums and museum architecture.

Received 9 $9^{\text {th }}$ January 2016

Finally accepted $11^{\text {th }}$ March 2016

\section{Note}

1 Despite using the term 'architecture' in a somewhat portmanteau way, we understand it throughout as both a professional practice and the built outcomes of such (Jones 2011; MacLeod 2013). 


\section{References}

Appaduri A. (1986) The Social Life of Things, Cambridge, MA: Cambridge University Press.

Bagnall G. (2003) 'Performance and Performativity at Heritage Sites', Museum

and Society, 1(2): 87-103.

Bagnall, G. and Rowland, A. (2010) 'The Imperial War Museum North: A

Twenty-First Century Museum?' in Crownshaw, R.; Kilby, J.; and A. Rowland, (eds.) The Future of Memory, New York and Oxford: Berghahn Books, pp. 51-76.

Baudrillard, J. (2005) The System of Objects. London: Verso.

Becker ([1982] 2008) Art Worlds. London: University of California Press.

Berger, P. and Luckmann, T. ([1965] 1991) The Social Construction of Reality. London: Penguin Books.

Bennett, T. (1995) The Birth of the Museum. London: Routledge.

Bennett, T. (2007) 'Habitus Clivé: Aesthetics and Politics in the Work of Pierre Bourdieu', New Literary History: A Journal of Theory and Interpretation, 38(1): 201-39.

Boast, R. (2011) 'Neocolonial Collaboration: Museum as Contact Zone Revisited', Museum Anthropology (34) 56-70.

Bonta, J-P. (1979) Architecture and its Interpretation, London: Lund Humphries.

Bourriaud, N. (2002) Relational Aesthetics, Dijon: Les Presses du Reel.

Bourdieu, P. (1984) Distinction: A Social Critique of the Judgement of Taste, trans., R. Nice, New York and London: Routledge and Kegan Paul.

Bourdieu, P. and Darbel, A. (1991) The Love of Art: European Art Museums and their Public, Cambridge: Polity Press. (trans., C. Beattie and N. Merriman)

Bourdieu, P. (1991) 'First Lecture: Social Space and Symbolic Space: Introduction to a Japanese Reading of Distinction', Poetics Today, 12v(4): 631.

Brawne, M. (1965) The New Museum: Architecture and Display, New York: Praeger Press.

Clifford, J. (1997) 'Museums as Contact Zones', Routes: Travel and translation in the late Twentieth Century, London: Harvard University Press.

Cuff, D. (1991) Architecture: The Story of Practice, Cambridge, Mass.: MIT Press.

Driver, F. and Ashmore, S. (2010) 'The Mobile Museum: Collecting and Circulating Indian Textiles in Victorian Britain', Victorian Studies 52 (3): 353-85.

Duncan, C. (1995) Civilizing Rituals: Inside Public Art Museums, London and New York: Routledge.

Duncan, C. and Wallach, A. (1978) 'The Museum of Modern Art as Late Capitalist Ritual: An Iconographic Analysis', Marxist Perspectives, 4, Winter

Duncan, C. and Wallach, A. (1980) 'The Universal Survey Museum', Art History, (3) 4 
Fallan, K. (2008) 'Architecture in Action: Travelling with Actor-Network Theory in the Land of Architectural Research', Architectural Theory Review 13(1): 80-96.

Fierro, A. (2006) The Glass State: The Technology of the Spectacle, Paris 1981-1998, MIT Press.

Forgan, S. (2005). 'Building the Museum': Knowledge, Conflict and the Power of Place', Isis 96 (4) 572-85.

Forty, A. (1996) 'Introduction' in Borden, I., Kerr, J., Pivaro, A., and Rendell, J. (eds.) Strangely Familiar: Narratives of Architecture in the City. London: Routledge.

Foucault, M. ([1970] 1997) The Order of Things: An Archaeology of the Human Sciences. London: Routledge.

Fuhrmann, J. (2015) 'Building "Objects of Desire": Workplace Studies and Reflections in the World of Architects'. Manuscript

Fyfe, G. (2011) 'Sociology and Social Aspects of the Museum', in MacDonald, S. (ed.) A Companion to Museum Studies. Oxford: Wiley-Blackwell, 33-49.

Gable, E. and Handler, R. (2007) 'After Authenticity at an American heritage site', in Knell, S. J. (ed.) Museums in the Material World, London: Routledge, 320-34.

Gibelhausen, M. (2002) 'The Architecture is the Museum', in Marstine, J. (ed.) New Museum Theory and Practice: An Introduction. Blackwell: Oxford.

Giebelhausen, M. (2003) The Architecture of the Museum: Symbolic Structures, Urban Contexts, Manchester: Manchester University Press.

Gieryn, T. F. (2002) 'What Buildings Do', Theory and Society, 31: 35-74.

Gieryn, T. F. (2006) 'The City as Truth Spot', Social Studies of Science 36(1): 5-8.

Glendinning, M. (2010) Architecture's Evil Empire: The Triumph and Tragedy of Global Modernism. London: Reaktion Books.

Guggenheim, M. (2013) 'Unifying and Decomposing Building Types: How to Analyse the Change of Use of Sacred Buildings', Qualitative Sociology 36 (4) 445-64.

Harbison, R. (1993) The Built, the Unbuilt and the Unbuildable. London: Thames and Hudson.

Imrie, R. and Kumar, M. (1998) 'Focusing on Disability and Access in the Built Environment', Disability \& Society 13(3): 357-74.

Imrie, R. (2012) 'Universalism, Universal Design, and Equitable Access to the Built Environment', Disability and Rehabilitation 34 (10) 873-888.

Jones, P. (2009) 'Putting Architecture in its Social Place: A Cultural Political Economy of Architecture', Urban Studies, 46 (12) 2519-36.

Jones, P. (2011) The Sociology of Architecture, Liverpool: Liverpool University Press.

Jones, P. (2014) 'Situating Universal Design Architecture: Designing With Whom?', Disability and Rehabilitation 36 (16) 1369-74.

Jones, P. (2016) '(Cultural) Sociologies of Architecture?', in Inglis, D. and Almila, A. (eds.) The SAGE Handbook of Cultural Sociology. London: Sage Press, 465-80. 
King, A. D. (ed.) (1980) Buildings and Society: Essays on the Social Development of the Built Environment, London: Routledge, Kegan \& Paul.

Latour, B. (2005) Reassembling the Social, Cambridge: Polity Press.

Latour, B. and Yaneva, A. (2008) 'Give me a Gun and I Will Make All Buildings Move: An ANT's View of Architecture', Explorations in Architecture: Teaching, Design, Research 80-9.

Lefebvre, H. (1991) The Production of Space. Oxford: Blackwell.

Levi-Strauss, C. (1995) Myth and Meaning: Cracking the Code of Culture. London: Shocken Press.

Lipstadt, H. (2003) 'Can "Art Professions" be Bourdieuean Fields of Cultural Production? The Case of the Architecture Competition', Cultural Studies, 30 (3-4), 319-40.

Macdonald, S. and Fyfe, G. (eds) (1998) Theorizing Museums, Oxford: Blackwell.

MacLeod, S., Hanks, L., and Hale, J. (eds) (2012) Museum Making: Narratives, Architectures, Exhibitions. London and New York: Routledge.

MacLeod, S. (2013) Museum Architecture: A New Biography, London: Routledge.

MacLeod, S., Dodd, J, and Duncan, T. (2014) 'New museum design cultures: harnessing the potential of design and "design thinking" in museums', Museum Management and Curatorship, 30 (4) 314-341.

Markus, T. (1993) Buildings and Power: Freedom and Control in the Origin of Modern Building Types, London: Routledge.

Marx, K. ([1852] 1970) 'The Eighteenth Brumaire of Louis Bonaparte', in Marx and Engels: Selected Works, London: Lawrence and Wishart.

Miles, S. (2010) Spaces for Consumption, London: Sage Publications.

Müller, A-M. and Reichamann, W. (eds) (2015) Architecture, Amteriality and Society: Connecting Sociology of Architecture with Science and Technology Studies, London: Palgrave.

Prior, N. (2005) 'A Question of Perception: Bourdieu, Art and the Postmodern', The British Journal of Sociology, 56 (1) 123-39.

Sabagh, K. (2001) 'Not in Front of the Architects', in Power into Art, London: Penguin Hardcover.

Shiner, L. (2007) 'Architecture v Art: The Aesthetics of Art Museum Design', Contemporary Aesthetics at http://www.contempaesthetics.org/newvolume/pages/article. php?articlelD $=487$ [last accessed January $\left.20^{\text {th }} 2016\right]$.

Steets (2015) 'Taking Berger and Luckmann into the Realm of Materiality: Architecture as Social Construction', Cultural Sociology 10 (1) 93-108.

Tafuri, M. ([1976] 1999) Architecture and Utopia. Cambridge, MA: MIT Press

Trodd, C. (2003) 'The Discipline of Pleasure or, How Art History looks at the Art Museum', Museum and Society, 1: 17-29.

Webster, H. (2010) Bourdieu for Architects, London: Routledge. 
Wilson, F. and Halle, H. (1993) 'Mining the Museum', Grand Street 44: 151-72.

Wolff, J. (1981) The Social Production of Art, London: MacMillan.

Woodham, A. (2009) Museums Visiting and Social Inclusion: the Geography of School Visits to Museums, University of Leicester, PhD Thesis.

Yaneva, A. (2003) 'When a Bus Met a Museum: Following Artists, Curators and Workers in an Art Installation', Museum and Society 1 (3) 116-31.

Yaneva, A. (2009) Made by the Office of Metropolitan Architecture: An Ethnography of Design. Amsterdam: Uitgeverij.

Yaneva, A. (2012) Mapping Controversies in Architecture, Farnham: Ashgate.

\section{Acknowledgements}

We are very grateful to the anonymous Museum and Society reviewers for their expert and constructive comments. As ever, the usual disclaimers apply.

* Paul Jones is a Senior Lecturer in Sociology at the University of Liverpool. His research centres on the political economy of the urban; recently this has included studies of architecture and the built environment, digital models, regeneration photography, and - with Michael Mair - analysis of the Private Finance Initiative, supermarkets, and contemporary state reform.

**Suzanne MacLeod is Director and Head of School of Museum Studies at University of Leicester. Her research interests relate to museum architecture and exhibition design with a focus on historical research, contemporary design, and the connections between them. She has developed a series of events and publications which explore contemporary museum design, with a particular focus on design methodologies and the acknowledgement of the interpretive potential of design.

Corresponding email: P.Jones01@liverpool.ac.uk 